\title{
Hypolipidimic Effects of Dried Tomato Pomace Powder on Aging Female Rats
}

\author{
Abeer A. Khedr ${ }^{\mathbf{1}}$, El-Beltagy, $\mathbf{A}^{\mathbf{2}}$ and Marwa, M Shabana \\ ${ }^{1}$ Department of Nutrition and Food Sciences, Faculty of Home Economics, Menufyia \\ University. Shibin El-Kom, Egypt \\ 2 Department of Food Sciences and Technology, Faculty of Agriculture, Menufyia \\ University, City: Shibin El-Kom Egypt
}

\section{ABSTRACT}

7 Tomato pomace is rich in bioactive food components, and has therapeutic properties but have a low economic value. In this paper, the effect of tomato

1 pomace on reduce lipid profile and improve antioxidant status in aging female rats, also the potential use of tomato pomace in bread were studied. Twenty four aging female rats were divided randomly into four groups, six rats per each. First (control group), second, third and fourth group received basal diet $+0,2.5,5$ and $10 \%$ of dried tomato pomace (DTP) respectively for 4 weeks. Animals were sacrificed, blood samples were collected. Serum was then removed by centrifuging for analysis. Also, tomato pomace powder was used to replace part of the whole wheat flour $(0 \%, 2.5 \%, 5 \%$ and 10\%) in standard baladi bread. Appearance, taste, flavor, texture, compressibility, color and overall acceptability were evaluated in baladi bread. $10 \%$ dried tomato pomace group was more effective to reduce serum total lipid (T.L), triglyceride (TG), total cholesterol (TC) and atherogenic indices levels than other groups. While, antioxidant status indicators improved in DTP groups and 10\% DTP had more effective. Moreover, sensory evaluation showen that all portion of DTP in bread were found acceptable by the panelists. It conclude that dried tomato pomace powder improved lipid profile levels and antioxidant status in aging female rats and it obtained good result in sensory evaluation of baladi bread.

Keywords: Aging female rats - dried tomato pomace- Hypolipidimic effects bread 
Abeer A. Khedr, El-Beltagy, A and Marwa, M Shabana

INTRODUCTION

Aging has been defined as natural, progressive and generalized deterioration process that occurs over time. Aging is directly related to homeostasis loss and with gradual dysfunction, that in many cases concurs with pathological situations and finally ends in death (Wheeler and Kim, 2011; López-Otín et al., 2013).

The principal causes of death in older people are cardiovascular diseases (CVD), stroke and chronic lung disorders. The World Health Organization (WHO) projected a scenario for 2030 in which CVD will maintain its position among the top causes of death in older adults, with females as the most vulnerable group (Silva-Palacios et al., 2016). Decreasing estrogen levels during the menopausal transition have been linked to endothelial dysfunction and larger vessel diameters, markers of early adverse vascular changes (Mendelsohn, 2002). Therefore, decreased estrogen following the menopausal transition leaves the vasculature vulnerable to CVD risk factors, such as lipids. Lifestyle characteristics are important determinants of healthy aging. Nutrition is a pivotal constituent of a healthy lifestyle, and epidemiological evidence links diets rich in fruits and vegetables, such as the Mediterranean diet, with healthy longevity (Bonaccio et al .,2012).

Tomato

(Lycopersicon esculentum) is a well-known plant that belongs to Solanaceae family and it is one of the widely consumed vegetables, either fresh or industrially processed (Aguayo et al., 2009). In the year 2006, the average annual production of tomato in Egypt was recorded to be 7.6 million tons resulting in production of $19 \%$ as by-product during manufacturing (FAO (2011). Unfortunately, a great part of this by-product is lost without utilization

(Aghajanzadeh-

Golshani et al., 2010).

Tomato pomace, as a byproduct, is a mixture of tomato skin, pulp and crushed seeds that remain after the processing of tomato for juice, paste and/or ketchup (Mirzaei-Aghsaghali et al., (2008); Nobakht and 


\section{Safamehr (2007) and Ventura et} al.,(2009)).

The dried tomato pomace has been considered as a good source of protein and natural pigments such as $\beta$ - carotene and lycopene as well as a valuable source of $\alpha$-tocopherol which is used as an antioxidant (Karadas et al., 2006 and King \& Zeidler 2004).

Tomato pomace could afford health benefits by preventing unwanted free radical induced oxidative reactions. It is necessary to consider both environmental (waste management and protection against pollution) aspects and economical aspects (extraction profitability) before the extracts from tomato residues could be commercially exploited. More research is needed to establish bioavailability (Sladjana et al., 2012).

Therefore, the present investigation aims to evaluate the effect of dried tomato pomace to reduce the levels of lipid profile and atherogenic indexes in aging female rats and study its application in food to utilization of it.

\section{MATERIALS \&METHODS}

\section{Materials:}

\section{Tomato pomace}

Tomato pomace as a waste during the preparation of tomato juice was obtained from Edfina Company for food preservation, Alexandria, Egypt.

\section{Animals:}

Twenty four aging female Sprague Dawley rats, $18-20$ months old, with an average body weight (B.W) $300 \pm 5 \mathrm{~g}$, were purchased from the Veterinary Medicine Institute, Cairo, Egypt. At the beginning of experiment, a3 $\mathrm{ml}$ of their blood samples were collected to determine lipids profile to make sure diagnosed with hyperlipidemia. Under normal laboratory conditions, with 12-hours light-dark cycle at $25 \pm$ $1{ }^{\circ} \mathrm{C}$, rats were housed in cylindrical wire cages with wire bottoms. The diet was introduced to rats in special food cups to avoid scattering of food. Also, water was provided to the rats by glass tube projection through the wire cage. Food and water provided and checked daily. Rats were fed standard diet according 
Abeer A. Khedr, El-Beltagy, A and Marwa, M Shabana

to AIN-93 guidelines (Reeves et al., 1993). All animals received care in compliance with the Egyptian rules for animal protection.

\section{Methods:}

Preparation of tomato pomace and chemical analysis:

Tomato pomace were dried in a laboratory oven dryer (Plue Pard Drying Oven, Taiwan) at $50^{\circ} \mathrm{C}$ milled by (Moulinex miller, France) to be a fine powder. Sample of the prepared tomato pomace was taken for estimating its chemical composition (moisture, protein, fat, ash and carbohydrates by difference) using the methods of A.O.A.C (2012). Total phenolic content expressed as gallic acid equivalent (GAE) was determined by the Folin-Ciocalteu micro-method according to Saeedeh and Asna, (2007). Total flavonoids content expressed as quercetin equivalent (QE) was determined by the method of Ordon et al., (2006). $\beta$-Carotene and lycopene was determined by Kimura's method according to Nagata and Yamashita, (1992). Antioxidant activity of tomato pomace extract was determined by
2, 2 diphenyl-1-picrylhydrazyl (DPPH) according to Yang et al., (2006).

\section{Experimental design:}

The rats were divided randomly into four groups, (6) rats per each. First (control group), second, third and fourth group received basal diet $+0,2.5,5$ and $10 \%$ of dried tomato pomace (DTP) respectively for 4 weeks. Animals were sacrificed under diethyl ether anesthesia. Blood samples were collected from the hepatic portal vein. The blood samples were placed in dry clean centrifuge tubes and allowed to clot for 1-2 $\mathrm{h}$ at room temperature. Serum was then removed by centrifuging at $1500 \mathrm{~g}$ for $10 \mathrm{~min}$. The clear supernatant serum was kept at $-20^{\circ} \mathrm{C}$ until analysis. Red blood cells were washed three times with buffered saline $(0.9 \%$ saline in $0.01 \mathrm{M}$ phosphate buffer, $\mathrm{pH}$ 7.4). The packed cells were then suspended in an equal volume of the buffered saline and stored at $-20{ }^{\circ} \mathrm{C}$ for antioxidant enzymes analysis. And Serum was carefully aspirated and transferred into clean cuvette tube and stored 
Abeer A. Khedr, El-Beltagy, A and Marwa, M Shabana

frozen at $-20^{\circ} \mathrm{C}$ for analysis according to the procedure of (Schermer, 1967).

\section{Biochemical assays:}

The serum triglycerides (TG), high density lipoprotein (HDL), total cholesterol (TC) and total lipids (TL) were determined according to the methods described by Fossati and Prencipe (1982) ; Demacker et al. (1980) ; Richmound, (1973) and Covaci et al., (2006) respectively. The determination of low density lipoprotein cholesterol (LDLc) and very low density lipoprotein cholesterol (VLDLc) were carried out according to the method of Lee and Nieman (1996) The Atherogenic ratios were calculated as follows: Atherogenic Index of Plasma $(\mathrm{AIP})=\log$ TG/HDLc, Cardiac risk ratio $(\mathrm{CRR})=\mathrm{TC} / \mathrm{HDLc}$ Castelli's Risk Index (CRI) = LDLc/HDLc Atherogenic Coefficient $(\mathrm{AC})=(\mathrm{TC}-$ HDLc)/HDLc according to Bhardwaj et al., (2013) and Atherogenic fraction (AF) was calculated as the difference between TC and HDL-C according to Aguilar et al., (2011). Thiobirbituric acid reactive substances (TBARS) was estimated according to the methods of Esterbauer and Cheeseman (1990) . Superoxide dismutase (SOD) and reduced glutathione (GSH.Rd) we-re assayed according to the methods of Misra and Fridovich (1972) and Beutler et al. (1963) respectively. Catalase (CAT) activity was determined by measuring the decomposition of hydrogen peroxide $(\mathrm{H} 2 \mathrm{O} 2)$ at 240 $\mathrm{nm}$ according to the method of Aebi (1983).

\section{Preparation of bread and sensory evaluation}

Balady bread was prepared by mixing $100 \mathrm{~g}$ of wheat flour $(82 \%$ extraction), $0.5 \mathrm{~g}$ of active dry yeast, $1.5 \mathrm{~g}$ of sodium chloride, $75-80 \mathrm{~mL}$ of water by hand for about $6 \mathrm{~min}$ to form the needed dough. DTP was used to replace part of the whole wheat flour $(0 \%, 2.5,5 \%$ and $10 \%)$ in a standard balady bread recipe The dough was left to ferment for $1 \mathrm{~h}$ at $30^{\circ} \mathrm{C}$ and $85 \%$ relative humidity, and was then divided 
Abeer A. Khedr, El-Beltagy, A and Marwa, M Shabana

into $125 \mathrm{~g}$ pieces. The pieces were arranged on a wooden board that had been sprinkled with a fine layer of bran and were left to ferment for about $45 \mathrm{~min}$ at the same temperature and relative humidity. The pieces of fermented dough were flattened to be about $20-\mathrm{cm}$ in diameter. The flattened loaves were proofed at $30-35^{\circ} \mathrm{C}$ and $85 \%$ relative humidity for 15 min and then were baked at 400 $500^{\circ} \mathrm{C}$ for $1-2 \mathrm{~min}$. The loaves were allowed to cool at room temperature for $2 \mathrm{~h}$ before being packed in polyethylene bags and stored at room temperature for sensory evaluation (Eissa et al., 2007). Samples of bread were subjected to organoleptic tests (by fifteen judges) according to Watts et al., (1989). Judging rang for appearance, taste, flavor, texture, compressibility, color and overall acceptability was as follow, Excellent (9-10), Very good (8 7), Good (5-6), Fair (3-4), Poor (1$2)$ and very poor (0-1).

\section{Statistical analysis:}

Results were expressed as the mean \pm SD. Data for multiple variable comparisons were analyzed by one-way analysis of variance (ANOVA). For the comparison of significance between groups, Duncan's test was used as a post hoc test according to the statistical package program (Artimage and Berry, 1987).

\section{RESULTS \& DISCUSSION}

The proximate chemical compositions and bioactive compounds of DTP presented in table (1). Tomato pomace contained 20.18\% moisture, $0.18 \%$ protein, $11.33 \%$ fat, $48.82 \%$ fiber, $14.78 \%$ carbohydrate and $4.71 \%$ ash. This result came in accordance with that reported by Elazab et al., (2011).

Also, the crude protein content of tomato pomace was similar to that reported by Taghizadeh et al., (2008). Fiber content of tomato pomace was similar to result of Chumpawadee and Pimpa, (2008) \& shao et al., (2013) which was $47.3 \%$. In the same table, data indicated that tomato pomace antioxidant activity was 
Abeer A. Khedr, El-Beltagy, A and Marwa, M Shabana

$41.25 \%$; this result was higher than the result obtained by Vallverd Queralt et al., (2011). Toor and savage, (2005) found that the skin of tomato had higher levels of antioxidant activity. In recent result, total phenolic compounds in tomato pomace were $6.40 \mathrm{mg}^{\mathrm{GAE}} \mathrm{g}^{-1}$. This results was in disagreeing with the given by Sladjana et al., (2012) and Farag et al., (2009).

Toor and savage (2005) found that the skin of tomato had higher levels of total phenolices, Tomato pomace contained 0.324 $\mathrm{QE} \mathrm{g}^{-1}$ flavonoids. Another study Sladjana et al., (2012) investigated a higher amount of total flavonoids in tomato waste $(7.62 \mathrm{mg} / \mathrm{g})$.

Also Stewart et al., (2000) reported that the majority of the flavonoids in tomato pomace present in skin. The amount of the lycopene in tomato pomace was $81.60 \mathrm{mg} / 100 \mathrm{mg}$. The result of this study came in accordance with that reported by Irini and Vassiliki (2011). Also, Sgorlon $\boldsymbol{e t}$ al., 2006 had confirmed that tomato pomace containing $1.3 \%$ lycopene. Toor and savage,
(2005) found that the skin of tomato had higher levels of lycopene. Interestingly, tomato pomace had a high $\beta$-Carotene amount (32.17 mg/100mg). The recent result disagree with that reported by Huang et al., (2008) and Irini and Vassiliki (2011).

The effect of adding dried tomato pomace powder on serum lipid profile in aging female rats is recorded in table (2). Rats which administrated basal diet alone $(0 \%$ DTP) were high significantly ( $\mathrm{P} \leq$ 0.05) than all groups in T.L, TG, TC, LDL and VLDL levels and low in HDL. (Paolo et al., 1999) confirmed the obtained result as who showed that plasma cholesterol levels increase with age, as does the incidence of coronary heart disease. While 10\% dried DTP were more effective $(\mathrm{P} \leq 0.05)$ to decrease T.L, TG, TC, LDL and VLDL levels, while HDL had opposite trend. Similar trend was observed for Elliott $\boldsymbol{e t}$ al., (1981) reported that 10\% TP supplementation resulted in significantly higher serum cholesterol than the control diet in rats. 
Abeer A. Khedr, El-Beltagy, A and Marwa, M Shabana

Elazab et al., (2011)
noticed that fed growing rabbits
on tomato pomace inclusion diets
resulted in a significant increase in
plasma cholesterol concentration
compared to the control group and
this effect was attributed to tomato
pomace level. Also recent result
correlates with results reported by Rahmatnejad et al .,(2009), Shao et al., (2013a) and (Bajerska et al., 2015) they reported that showed that dried tomato pomace lowered plasma TC and low-density lipoprotein cholesterol (LDLC) concentrations and increased fat excretion. They suggest that protein, dietary fiber or phenolic compounds in dried tomato pomace may be responsible for plasma cholesterol decrease. Lycopene accumulates in the liver and can inhibit the activity of the rate-limiting enzyme of cholesterol biosynthesis (Navarro-González et al., 2014).

While Shao et al., (2013a) reported that there were no significant differences of plasma TG concentration between all the tomato sample groups and their corresponding controls, and they showed that VLDL-C in DTS fed animals were also lower although not statistically significantly. Decrease plasma total lipids concentration in tomato pomace groups was attributed to increase lipid metabolism and transfer these lipids from blood to adipose tissues (Elazab et al., 2011).

Effect of dried tomato pomace powder on atherogenic indices and HDL/TC ratio $\mathrm{HTR} \%$ in aging female presented in table (3). The groups which administrated DTP were significantly $(p \leq 0.05)$ decrease in AIP, CRR, CRI, AF and $\mathrm{AC}$ and increase in HTR\% than the group which feed basal diet alone. More considerable reduction $(\mathrm{p} \leq 0.05)$ in AIP, CRR, $\mathrm{CRI}, \mathrm{AF}$ and $\mathrm{AC}$ were observed in rats administrated with $10 \%$ DTP group compared to other aging female groups followed by 5\% DTP group, and 2.5\% DTP group. Also, the group which taken $10 \%$ DTP had more improvement in HTR\% than other DTP group. Atherogenic indices are powerful indicators of the risk of heart disease the higher the value, the 
Abeer A. Khedr, El-Beltagy, A and Marwa, M Shabana

higher the risk of developing Cardiovascular Disease (CVD) and vice versa (Usoro et al., 2006).

Bajerska et al., (2015) repored that rye bread with tomato pomace lowering the atherogenic index of plasma (AIP) by $31.6 \%$. Shao et al., (2013a) suggested that tomato pomace by products especially dried tomato pomace has hypocholesterolemic properties and may be a food ingredient that prevents cardiovascular disease.

Table (4) summarized the effect of adding dried tomato pomace powder to aging female rats in antioxidant status. The level of SOD, CAT and GSH in $10 \%$ DTP group were significantly $(\mathrm{p} \leq 0.05)$ high when compared with the corresponding value $0 \%$ DTP group and the other aging female groups which received dried DTP , followed by $5 \%$ DTP group and 2.5\% DTP group, respectively. On the other side, the mean value of MAD in $10 \%$ DTP groups was significantly $(\mathrm{p} \leq 0.05)$ lower than other groups which were $3.32 \pm 0.29$, followed by $5 \%$ DTP group $4.14 \pm 0.14$, followed by $2.5 \%$ DTP group $7.63 \pm 0.34$ respectively. Malondialdehyde (MDA) is a degradation product generated from lipid peroxidation (oxidative degradation of polyunsaturated fatty acids in cell membrane). MDA has been extensively used as an index for lipid peroxidation and as a marker for oxidative stress (Kubow, 1992). Additionally, there is high oxidative stress (increased plasma level of malondialdehyde, MDA) as well as decreased activity of antioxidant enzymes, especially superoxide dismutase (SOD) (Aluko and Udenigwe 2012). Bose and Agrawal, (2007) confirmed the obtained result as who reported that lycopene decreased liped peroxidation in cardiovascular patients. GSH is one of the essential compounds for maintaining cell integrity participation in the cell metabolism. This result may occur because the accumulation of oxidized proteins during aging is most likely linked to an agerelated decline of antioxidant enzyme activity, whereas lipid peroxidation is less sensitive to the 
Abeer A. Khedr, El-Beltagy, A and Marwa, M Shabana

aging process (Tian and Wei 1998). Results consistently show improved antioxidant status with tomato products consumption (Kucuk et al., 2002).

Elazab et al., (2011) reported that lycopene from tomato reduced MAD but contrast increased antioxidant enzymes like GSH and SOD .Also , lycopene decreased lipid peroxidation in cardiovascular patients according to Bose \& Agrawal ,2007. This result may occur because the accumulation of oxidized protein during aging is the most likely linked to an agerelated decline of antioxidant enzyme activity, whereas lipid peroxidation is less sensitive to the aging process according to Tian and Wei (1998).

Also, Sgorlon et al., (2006) had confirmed that tomato pomace was able to counterbalance oxidative stress in sheep.

Data given in table

showed the effect of dried tomato pomace powder on weights change of aging female rats. No significant $(\mathrm{P}>0.05)$ difference in Initial body weights between all group. 10\% dried DTP group had a lower final body weight than all other DTP groups and the group which received basal diet alone (control group). Body weight gain was higher in control group than that which administrated DTP group. But, 10\% DTP group showed a reduction of $14.7 \%$ in body weight gain. This finding came in accordance with that reported by Sayed and AbdelAzeem (2009) who indicated the presence of higher daily gains for rabbits fed the diet contained $20 \%$ dried tomato pomace; while rabbits fed on the $30 \%$ dried tomato pomace level recorded the lowest value of daily gain. However the previous study by Abd El-Razik (1996) reported that there were no significant differences in live body weight, total or daily weight gain between experimental rabbit groups feed diets containing $0,5,10 \%$ tomato pomace for 8 weeks.

Similarly, Shao et al., (2013) observed that the tomato pomace displayed significantly higher body weight gain compared to its control containing the same high level $(25 \%)$ of dietary fiber 
Abeer A. Khedr, El-Beltagy, A and Marwa, M Shabana

$(\mathrm{P}<0.05)$. These effects of DTP on reducing body weight may be due to high content of fiber in tomato pomace.

Sensory evaluation of baladi breads prepared with dried tomato pomace powder portions table (6). There were significant $(\mathrm{P} \leq 0.05)$ decrease in appearance and taste in bread prepared with DTP portion $(2.5,5$, and $10 \%)$ which was similar compared with control bread. In flavor of bread which prepared with $0,2.5$ and 5\% DTP were similar and were significant (P $\leq 0.05)$ increase than bread which prepared with $10 \%$ DTP. Color in bread which prepared with $2.5 \%$ DTP was non significantly with $0 \% \quad$ DTP (control) and there increase (P $\leq 0.05)$ than other DTP bread. In the same table, no significant ( $>0.05$ ) differences were observed in texture, compressibility and overall acceptability of breads prepared with DTP portion $(0,2.5,5$, and $10 \%)$. Similar trend was observed by Sik and Topkaya,(2016), who studied that use of tomato pomace in crackers and the crackers were liked statistically equally by the panelists.

Also, Bhat and Ahsan, (2015) added different levels ( 0,5 , $10,15,20$ and $25 \%$ ) of tomato pomace powder to cookies. Sensory evaluation revealed that overall desirability scores were not significantly different between control and tomato pomace powder incorporated cookies. The cookies up to $5 \%$ substitution of powder were found acceptable by the consumer

\section{REFRENCE}

A.O.A.C. (2012):

International Official

Methods of Analysis, $19^{\text {th }}$ ed., Gaithersburg.

Abd El-Razik, W.A. (1996):

Effect of substitution of tomato pomace for corn in growing rabbit diets on growth performance and carcass traits. Egyptian J. Rabbit Sci. 6: 79-86.

Aebi H (1983): 
Abeer A. Khedr, El-Beltagy, A and Marwa, M Shabana

Catalase in vitro. Methods

Enzymol .,105: 121-126.

\section{Aghajanzadeh-Golshani}

A;

Maheri-Sis N; Mirzaei-

Aghsaghali A and

Baradaran- Hasanzadeh

A (2010):

Comparison of nutritional value of tomato pomace and brewer's grain for ruminants using in vitro gas production technique. Asian J. Anim. Vet. Adv. 5: 43-51.

Aguayo IA; Fortuny RS and Belloso OM (2009):

Volatile compounds and changesin flavour-related enzymes during cold storage of high-intensity pulsed electric field and heat-processed tomato juices. Journal of the Science of Food andAgriculture, 90, 15971604.

\section{Aguilar EC; Queiroz MGMN and Oliveira DA (2011):}

Serum lipid profile and hepatic evaluation in mice fed diet containing pequinut or pulp (Caryocar brasiliense Camb.) . Ciênc. Tecnol. Aliment., Campinas, 31(4): 879-883, out.-dez. 2011.

Aluko RE and Udenigwe CC (2012):

Food Protein-Derived Bioactive Peptides: Production, Processing, and Potential Health Benefits. Journal of Food Science 77 (1), R11-R24.

Artimage GY and Berry WG (1987):

Statistical Methods 7th Ed. Ames, Iowa State University Press, 39-63.

Bajerska J; Chmurzynska A; Mildner-Szkudlarz $S$ and Drzymała-Czyż S (2015):

Effect of rye bread enriched with tomato pomace on fat absorption and lipid metabolism in rats fed a high-fat diet. $J$ 
Sci Food Agric. Jul; 95 (9):1918-24. doi: 10.1002/jsfa.6899.

\section{Beutler E; Duron $O$ and Kelly} BM (1963):

An improved method for the detection of blood glutathione. J. Lab. Clin. Med., 61: 882-888.

Bhardwaj S; Bhattacharjee J; Bhatnagar MK and Tyagi S (2013):

Atherogenic index of plasma, castelli risk index and atherogenic coefficient- new parameters in assessing cardiovascular risk. IJPBS. 3(3) :359-364.

\section{Bhat MA and Ahsan H (2015):}

Physico-Chemical

Characteristics of Cookies Prepared with Tomato Pomace Powder. J Food Process Technol 2015, (7):1. 543.
Bobek P (1999):

Dietary tomato and grape pomace in rats: effect on lipids in serum and liver, and on antioxidant status. $\mathrm{Br} J$ Biomed Sci.;56 (2):109-13.

Bonaccio M; Iacoviello L; de Gaetano $G$ and Moli-Sani Investigators (2012):

The Mediterranean diet: the reasons for a success. Thrombosis Research; 129:4014.

Bose KS and Agrawal; BK (2007):

Effect of lycopene from cooked tomatoes on serum antioxidant enzymes, lipid peroxidation rate and lipid profile in coronary heart disease. Singapore Med $J ; 48: 415-20$.

\section{Casterelli $T$ and Levitar $Y$} (1977):

Atherogenic Index. Curr. Presc., 39. 
Abeer A. Khedr, El-Beltagy, A and Marwa, M Shabana

Chumpawadee $S$ and Pimpa $O$ (2008):

Effect of non-forage high fibrous feedstuffs as fiber sources in total mixed ration on gas producttion characteristics and in vitro fermentation. Pak. J. Nutr., 7: 459-464.

Covaci AV; Thomsen S $C$; Van BB and Neels $H$ (2006):

Evaluation of Total Lipids Using Enzymatic Methods for the Normalization of Persistent Organic Pollutant Levels in Serum. Science of the Total Environment., 366 (1): 361-366.

Demacker PM; Von-janssen, HE and Hifman AM (1980):

Vants lear, A. and jansen, A.P. Measurment of high density lipoprotein cholesterol in serum. Comparison of six isolation methods combined with enzymatic cholesterol analysis. Clin.

Chem., 26:1780-1789.

Eissa HA; Hussein AS and Mostafa BE (2007):

Rheological properties and quality evaluation of Egyptian balady and biscuits supplemented with flours of ungerminated and germinated legume seeds or mushroom. Pol. J. Food Nutr. Sci. 57, (4). 487-496

Elazab MA; Zahra, SM; Ahmed MH and Elkomi AE (2011):

Productive performance of growing rabbits fed diet containing different levels of tomato pomace. BENHA VETERINARY MEDICAL JOURNA L, VOL. 2 2, NO.2, D EC.2011: 46-57.

Elliott, J., Mulvihill, E., Duncan, C., Forsythe, R. and Kritchevsky, D. (1981):

Effects of tomato pomace and mixed - vegetable pomace on serum and liver 
Abeer A. Khedr, El-Beltagy, A and Marwa, M Shabana

cholesterol in rats. Journal of Nutrition, 111 (12), 2203-2211.

Esterbauer $H$ and Cheeseman KH (1990):

Determination

of

aldehydic

lipid

peroxidation products:

malonaldehyde and 4-

hydroxynonenal. Meth.

Enzymol., 186: 407-421.

FAO (2011):

FAO Statistical (FAO STAT). Crop Statistics Food and Agriculture Organization of the United Nations.<http://faostat3.fao .org/home/index.html\#DO WNLOAD>

Farag MA; Huhman DV; Dixon RA and Sumner LW (2009):

Metabolomics reveals novel pathways and differential mechanistic and elicitorspecific responses in phenylpropanoid and isoflavonoid biosynthesis
Fossati $P$ and Prencipe I (1982):

Serum triglycrides determination colorimetrically with an enzyme that produce hydrogen peroxide. Clin.Chem, 28: 2077-2083.

Huang X; Fleming S; Alessi DR Woods YL and McBurnie W (2008):

Important role of the LKB1-AMPK pathway in suppressing tumorigenesis in PTEN-deficient mice. Biochem. J. 412:211-221.

Irini FS and Vassiliki O (2011):

Process optimisation for recovery of carotenoids from tomato waste. Food Chemistry 129 (2011) 747752. 
Abeer A. Khedr, El-Beltagy, A and Marwa, M Shabana

\section{Karadas F; Surai P; \\ Grammenidis E; Sparks \\ NH and Acamovic T (2006): \\ Supplementation of the maternal diet with tomato powder and marigold extract: effects on the antioxidant system of the developing quail. $\mathrm{Br}$. Poult. Sci. 47: 200208.}

King AJ and Zeidler G (2004):

Tomato pomace may be a good source of vitamin $\mathrm{E}$ in broiler diets. Calif. Agric. 58: 59-62.

\section{Kubow S (1992):}

Routes of formation and toxic con sequences of lipid oxidation products in foods. Free Rad. Biol. Med., 12: 63-81

\section{Kucuk O; Sarkar FH and} Djuric Z (2002):

Effects of lycopene supplementation in patients with localized prostate cancer. Exp Biol Med

(Maywood). 227:881-885.

Lee $R$ and Nieman D (1996):

Nutritional assessment. $2^{\text {nd }}$ Ed., Mosby, Missouri.

López-Otín C; Blasco MA; Partridge L; Serrano $M$ and Kroemer G (2013):

The hallmarks of aging. Cell 153, 1194-1217

Mendelsohn ME (2002):

Protective effects of estrogen on the cardiovascular system. Am $J$ Cardiol. 89(12A):12E17E. discussion 17E-18E. [PubMed]

Mirzaei-Aghsaghali A; Maheri-Sis N; MirzaAghazadeh A; Safaei AR and AghajanzadehGolshani A (2008):

Nutritional Value of Alfalfa Varieties for Ruminants with Emphasis on Different Measuring Methods: A Review. 
Research J. Biol. Sci. 3: 1227-1241.

Misra HP and Fridovich I (1972):

The role of superoxide anion in the autoxidation of epinephrine and a simple assay for superoxide dismutase. $J$. Biol. Chem., 247: 31703175.

Nagata $M$ and Yamashita $A$ (1992):

Simple method for simultaneous

determination of chlorophyll and carotenoids in tomato fruit. J. Japan. Soc.Food Sci.Technol. 39(10): 925928.

Navarro-González I; PérezSánchez H; MartínPozuelo G; GarcíaAlonso J and Periago MJ (2014):

The Inhibitory Effects of Bioactive Compounds of Tomato Juice Binding to

\section{Nobakht A and Safamehr AR} (2007):

The effects of inclusion different levels of dried tomato pomace in laying hens diets on performance and plasma and egg yolk cholesterol contents. $J$. Anim. Vet. Adv. 6: 11011106.

Ordon JD; Gomez MA and Vattuone MI (2006):

Antioxidant activities of Sechium edule (Jacq.) Swartz extracts. Food Chem., 97: 452-458.

Paolo Parini, Bo Angelin, Mats Rudling.(1999):

Cholesterol and Lipoprotein Metabolism in Aging Reversal of Hypercholesterolemia by Growth Hormone 
Abeer A. Khedr, El-Beltagy, A and Marwa, M Shabana

Treatment in Old Rats.

Original Contributions.

Rahmatnejad E; Bojarpour M; Mirzadeh KH; Chaji M and Ashayerzadeh $O$ (2009):

The effect of different levels of dried tomato pomace on broilers chicken hematological indices. $J$. Anim. Vet. Adv. 8(10): 1680-5593.

\section{Reeves PG; Nielsen F $\mathbf{H}$ and} Fahey GC (1993):

AIN-93 purified diets for laboratory rodents: final report of the American Institute of Nutrition ad hoc writing committee on the reformulation of the AIN-76A rodent diet. Journal of Nutrition, 123: 1939-1951. enzymatic assay of total cholesterol in serum .Clin. Chem., 19(12): 1350-6.
Saeedeh A and Asna U (2007): Antioxidant properties of various solvent extracts of mulberry (Morus indica L.) leaves. Food Chem., 102: 1233-1240.

Sayed AN and Abdel-Azeem, AM (2009):

Evaluation of dried tomato pomace as feedstuff in the diets of growing rabbits. IJAVMS. 3:13-18

\section{Schermer S (1967):}

The Blood Morphology of Laboratory Animals: The Blood Morphology of Laboratory Animals, $3^{\text {rd }}$ ed., F. A. Davis ed., F. A. Davis Company, 5- 4.

\section{Richmound W (1973):}

Preparation

and properties of cholesterol oxidas from Nacadia sp. And its application to
Sgorlon S; Stradaioli G; Zanin $D$ and Stefanon B (2006): Biochemical and molecular responses to 
antioxidant

supplementation in sheep.

Small Rumin Res. 64:143151.

\section{Shao D; Bartley GE;} Yokoyama W; Pan Z; Zhang $H$ and Zhang $A$ (2013a):

Plasma and hepatic cholesterol-lowering

effects of tomato pomace, tomato seed oil and defatted tomato seed in hamsters fed with high-fat diets. Food Chemistry 139: 589-596

Shao Z; Watanabe S; Christensen R; Jorgensen EM and Colon-Ramos D A (2013b):

Synapse location during growth depends on glia location. Cell, 154, 337-50.

Sik F and Topkaya C (2016):

Effects of tomato pomace supplementation on chemical and nutritional properties of crackers Ital. J. Food Sci., vol 28,
Silva-Palacios A; Königsberg $M$ and Zazueta $C$ (2016): Nrf2 signaling and redox homeostasis in the aging heart: A potential target to prevent cardiovascular diseases? Ageing Research Reviews 26. 81-95.

Sladjana M; Savatovic G; Cetkovic S; Jansana M; Čanadanovic-Bruunet and Sonja MD (2012):

Linetic behavior of the DPPH radical-scavenging activity of tomato waste extracts. J. Serb. Chem. Soc. 77 (10) 1381-1389.

Stewart AJ; Bozonnet S; Mullen W; Jenkins GI; Lean MEJ and Crozier A (2000):

Occurrence of flavonols in tomatoes and tomato-based products. J Agric Food Chem 48:2663-2669. 
Abeer A. Khedr, El-Beltagy, A and Marwa, M Shabana

\section{Taghizadeh A; Safamehr A; Palangi $\mathrm{V}$ and Mehmannavaz Y (2008): \\ The determination of metabolizable protein of some feedstuffs used in ruminant. Res. J. Biol. Sci., 3: 804-806.}

Tian CQ and Wei H (1998):

Alterations of antioxidant enzymes and oxidative damage to macromolecules in different organs of rats during aging. Free Radic Biol Med 24(9): 14771484.

Toor RK and Savage GP (2005):

Antioxidant activity in different fractions of tomatoes. Food Res Int 38:487-494.

Usoro CAO; Adikwuru CC; Usoro IN and Nsonwu AC(2006):

"Lipid Profile of Postmenopausal Women in
Calabar, Nigeria". Pak. J. Nutr. 5:79-82.

Vallverd- Queralt A; Odriozola-Serrano I; Oms-Oliu G; LamuelaRavents RM; ElezMartìnez $P$ and MartìnBelloso O (2011):

Changes in the polyphenol profile of tomato juices processed by pulsed electric fields. J Agri Food Chem, 60(38):9667-9672.

Ventura MR; Pieltin MC and Castanon JIR. (2009):

Evaluation of tomato crop byproducts as feed for goats. Anim. Feed Sci. Technol. 154: 271-275.

Watts BM; Yumaki CL; Jeffery LE and Elais LG (1989):

Basic sensory methods for food evaluation. The International Development Research Centre, Ottawa, Canada. p. 159. 
Abeer A. Khedr, El-Beltagy, A and Marwa, M Shabana

\begin{tabular}{ll}
\hline Wheeler H and Kim H (2011): & pericarp tissues of litchi \\
Genetics and genomics of & (Litchi chinensisSonn.) \\
human ageing. Philos. & fruit in relation to their \\
Trans. R. Soc. Lond. B & antioxidant activities. \\
Biol. Sci. 366, 43-50 & Carbohydrate Research, \\
http://dx.doi.org/10.1098/r & 341: 634-638. \\
stb.2010.0259 &
\end{tabular}

\section{Yang B; Wang JS and Zhao}

MM (2006):

Identification of

polysaccharides from 
Table (1): Chemical composition and bioactive compounds of tomato pomace

\begin{tabular}{|c|c|}
\hline Parameters & Tomato Pomace \\
\hline \multirow{2}{*}{ Moisture\% } & $20.82 \pm$ \\
\hline & 1.15 \\
\hline \multirow{2}{*}{ Ash\% } & $4.71 \pm$ \\
\hline & 0.05 \\
\hline \multirow{2}{*}{ Protein \% } & $0.18 \pm$ \\
\hline & 0.06 \\
\hline \multirow{2}{*}{ Fat $\%$} & $11.33 \pm$ \\
\hline & 0.58 \\
\hline \multirow{2}{*}{ Fiber\% } & $48.82 \pm$ \\
\hline & 0.46 \\
\hline \multirow[t]{2}{*}{ Carbohydrate\% } & $14.78 \pm$ \\
\hline & 0.18 \\
\hline \multirow[t]{2}{*}{ Antioxidant activity \% } & $41.25 \pm$ \\
\hline & 0.67 \\
\hline \multirow[t]{2}{*}{ Total phenolic ( mg GAE. ${ }^{-1}$ ) } & 6.40 \\
\hline & \pm 1 \\
\hline \multirow[t]{2}{*}{ Total flavonoid (mg QE. $\mathrm{g}^{-1}$ ) } & $0.324 \pm$ \\
\hline & 0.00 \\
\hline \multirow[t]{2}{*}{ lycopene(mg/100mg) } & $81.60 \pm$ \\
\hline & 0.38 \\
\hline \multirow{2}{*}{ B-Carotene (mg/100mg) } & $32.17 \pm$ \\
\hline & 1.01 \\
\hline
\end{tabular}

Each value in the table is the mean \pm standard deviation of three replicates.

Table (2): Effect of DTP on serum lipid profile in aging female rats 
Abeer A. Khedr, El-Beltagy, A and Marwa, M Shabana

\begin{tabular}{|l|c|c|c|c|}
\hline \multirow{2}{*}{$\begin{array}{c}\text { Groups } \\
\text { Parameters }\end{array}$} & $\begin{array}{c}\text { Aging female rats } \\
\text { (control) }\end{array}$ & $\mathbf{2 . 5 \%}$ DTP & $\mathbf{5 \%}$ DTP & $\mathbf{1 0 \%}$ DTP \\
\hline T. L. $(\mathbf{m g} / \mathbf{d l})$ & $451.12^{\mathrm{a}} \pm 2.98$ & $396.23^{\mathrm{b}} \pm 2.48$ & $315.27^{\mathrm{c}} \pm 1.96$ & $262.16^{\mathrm{d}} \pm 2.37$ \\
\hline T. G. $(\mathbf{m g} / \mathbf{d l})$ & $175.36^{\mathrm{a}} \pm 1.64$ & $146.77^{\mathrm{b}} \pm 1.66$ & $109.5^{\mathrm{c}} \pm 1.23$ & $90.84^{\mathrm{d}} \pm 1.54$ \\
\hline T. C. $(\mathbf{m g} / \mathbf{d l})$ & $193.22^{\mathrm{a}} \pm 1.15$ & $178.17^{\mathrm{b}} \pm 0.60$ & $150.14^{\mathrm{c}} \pm 0.43$ & $124.88^{\mathrm{d}} \pm 0.37$ \\
\hline HDL $(\mathbf{m g} / \mathbf{d l})$ & $16.86^{\mathrm{d}} \pm 0.66$ & $21.17^{\mathrm{c}} \pm 0.10$ & $24.23^{\mathrm{b}} \pm 0.16$ & $28.84^{\mathrm{a}} \pm 0.29$ \\
\hline LDL $(\mathbf{m g} / \mathbf{d l})$ & $141.2^{\mathrm{a}} \pm 1.28$ & $127.64^{\mathrm{b}} \pm 0.54$ & $104.01^{\mathrm{c}} \pm 0.35$ & $77.87^{\mathrm{d}} \pm 0.09$ \\
\hline VLDL(mg/dl) & $35.07^{\mathrm{a}} \pm 0.33$ & $29.35^{\mathrm{b}} \pm 0.33$ & $21.78^{\mathrm{c}} \pm 0.45$ & $18.15^{\mathrm{d}} \pm 0.32$ \\
\hline
\end{tabular}

Data are expressed as mean $\pm S D$. Values within a row having different superscripts are significantly different $(p \leq 0.05)$; where the small letters indicate significant among dietary treatment groups as indicated by one-way ANOVA followed by Duncan's multiple range test $(a>b>c>d>e)$.

Table (3): Effect of DTP on atherogenic indices and HTR\% in aging female rats

\begin{tabular}{|c|c|c|c|c|}
\hline \multirow{2}{*}{$\begin{array}{r}\text { garoups } \\
\text { Parameters }\end{array}$} & \multicolumn{4}{|c|}{ Aging female rats } \\
\cline { 2 - 5 } & $\begin{array}{c}\mathbf{0 \%} \text { DTP } \\
(\text { control })\end{array}$ & $\mathbf{2 . 5 \%}$ DTP & 5\% DTP & $\mathbf{1 0 \%}$ DTP \\
\hline $\begin{array}{c}\text { AIP } \\
\text { (mg/dl) }\end{array}$ & $1.01^{\mathrm{a}} \pm 0.02$ & $0.83^{\mathrm{b}} \pm 0.01$ & $0.65^{\mathrm{c}} \pm 0.01$ & $0.49^{\mathrm{d}} \pm 0.01$ \\
\hline $\mathbf{C R R}$ & $11.47^{\mathrm{a}} \pm 0.45$ & $7.97^{\mathrm{b}} \pm 0.97$ & $6.16^{\mathrm{c}} \pm 0.84$ & $4.31^{\mathrm{d}} \pm 0.03$ \\
\hline $\begin{array}{c}\text { CRI } \\
\text { (mg/dl) }\end{array}$ & $8.38^{\mathrm{a}} \pm 0.38$ & $6.02^{\mathrm{b}} \pm 0.03$ & $4.28^{\mathrm{c}} \pm 0.03$ & $2.69^{\mathrm{d}} \pm 0.2$ \\
\hline AF (mg/dl) & $51.93^{\mathrm{a}} \pm 0.94$ & $50.53^{\mathrm{b}} \pm 0.36$ & $46.14^{\mathrm{c}} \pm 0.20$ & $47.01^{\mathrm{d}} \pm 0.42$ \\
\hline $\mathbf{A C}$ (mg/d) $)$ & $10.47^{\mathrm{a}} \pm 0.45$ & $7.40^{\mathrm{b}} \pm 0.05$ & $5.19^{\mathrm{c}} \pm 0.05$ & $3.32^{\mathrm{d}} \pm 0.04$ \\
\hline HTR\% & $0.08^{\mathrm{d}} \pm 0.00$ & $0.11^{\mathrm{c}} \pm 0.01$ & $0.16^{\mathrm{b}} \pm 0.00$ & $0.23^{\mathrm{a}} \pm 0.00$ \\
\hline
\end{tabular}

Data are expressed as mean $\pm S D$. Values within a row having different superscripts are significantly different $(p \leq 0.05)$; where the small letters indicate significant among dietary treatment groups as indicated by one-way ANOVA followed by Duncan's multiple range test $(a>b>c>d>e)$ 
Table (4) : :Effect of DTP on antioxidant status in aging female rats .

\begin{tabular}{|c|c|c|c|c|}
\hline \multirow{2}{*}{$\begin{array}{r}\text { groups } \\
\text { Parameters }\end{array}$} & \multicolumn{4}{|c|}{ Aging female rats } \\
\cline { 2 - 5 } & $\begin{array}{c}\text { 0\% DTP } \\
\text { (control) }\end{array}$ & $\mathbf{2 . 5 \%}$ DTP & 5\% DTP & 10\% DTP \\
\hline SOD(u/ml) & $190.30^{\mathrm{d}} \pm 0.70$ & $210.45^{\mathrm{c}} \pm 0.37$ & $227.76^{\mathrm{b}} \pm 0.31$ & $235.41^{\mathrm{a}} \pm 0.82$ \\
\hline $\mathbf{C A T}(\mathbf{U} / \mathbf{L})$ & $16.95^{\mathrm{c}} \pm 1.46$ & $17.92^{\mathrm{c}} \pm 1.23$ & $20.37^{\mathrm{b}} \pm 1.70$ & $23.65^{\mathrm{a}} \pm 1.35$ \\
\hline $\mathbf{G S H}(\mathbf{U} / \mathbf{L})$ & $0.18^{\mathrm{d}} \pm 0.01$ & $0.20^{\mathrm{c}} \pm 0.01$ & $0.28^{\mathrm{b}} \pm 0.01$ & $0.34^{\mathrm{a}} \pm 0.14$ \\
\hline $\begin{array}{c}\text { MAD } \\
(\mathbf{n m o l} / \mathbf{m l})\end{array}$ & $8.45^{\mathrm{a}} \pm 0.30$ & $7.63^{\mathrm{b}} \pm 0.34$ & $4.14^{\mathrm{c}} \pm 0.14$ & $3.32^{\mathrm{d}} \pm 0.29$ \\
\hline
\end{tabular}

Data are expressed as mean $\pm S D$. Values within a row having different superscripts are significantly different $(p \leq 0.05)$; where the small letters indicate significant among dietary treatment groups as indicated by one-way ANOVA followed by Duncan's multiple range test $(a>b>c>d>e)$

Table (5): Effect of DTP on weights change of aging female rats .

\begin{tabular}{|c|c|c|c|c|}
\hline \multirow{2}{*}{$\begin{array}{c}\text { groups } \\
\text { Parameters }\end{array}$} & \multicolumn{4}{|c|}{ Aging female rats } \\
\cline { 2 - 5 } & $\begin{array}{c}\text { 0\% DTP } \\
\text { (control) }\end{array}$ & $\mathbf{2 . 5 \%}$ DTP & 5\% DTP & $\mathbf{1 0 \% ~ D T P ~}$ \\
\hline $\begin{array}{c}\text { Initial } \\
\text { weight }\end{array}$ & $304.0^{\mathrm{a}} \pm 1.20$ & $303.6^{\mathrm{a}} \pm 0.89$ & $303.4^{\mathrm{a}} \pm 1.54$ & $303.8^{\mathrm{a}} \pm 1.30$ \\
\hline Final weight & $358.2^{\mathrm{a}} \pm 1.92$ & $321.8^{\mathrm{b}} \pm 4.32$ & $287.6^{\mathrm{c}} \pm .6 .50$ & $259.2^{\mathrm{d}} \pm 2.7$ \\
\hline Changes & 54.2 & 18.2 & -15.8 & -44.6 \\
\hline
\end{tabular}

Data are expressed as mean $\pm S D$. Values within a row having different superscripts are significantly different $(p \leq 0.05)$; where the small letters indicate significant among dietary treatment groups as indicated by one-way ANOVA followed by Duncan's multiple range test $(a>b>c>d>e)$ 
Table (6): Sensory evaluation of breads prepared with dried tomato pomace portions.

\begin{tabular}{|c|c|c|c|c|}
\hline \multirow{2}{*}{$\begin{array}{c}\text { Bread } \\
\text { Parameters }\end{array}$} & \multicolumn{4}{|c|}{ Dried tomato pomace portions } \\
\cline { 2 - 5 } & $\mathbf{0 \%}$ & $\mathbf{2 . 5 \%}$ & $\mathbf{5 \%}$ & $\mathbf{1 0 \%}$ \\
\hline $\begin{array}{c}\text { Appearance } \\
\text { Taste }\end{array}$ & $9.12^{\mathrm{a}} \pm 0.35$ & $7.75^{\mathrm{b}} \pm 0.46$ & $7.62^{\mathrm{b}} \pm 0.51$ & $7.50^{\mathrm{b}} \pm 0.53$ \\
\hline Flavor & $9.37^{\mathrm{a}} \pm 0.35$ & $8.31^{\mathrm{b}} \pm 0.59$ & $8.18^{\mathrm{b}} \pm 0.37$ & $8.0^{\mathrm{b}} \pm 0.27$ \\
\hline Texture & $9.63^{\mathrm{a}} \pm 0.44$ & $9.37^{\mathrm{a}} \pm 0.44$ & $9.31^{\mathrm{a}} \pm 0.37$ & $8.0^{\mathrm{b}} \pm 0.71$ \\
\hline compressibility & $9.63^{\mathrm{a}} \pm 0.35$ & $9.48^{\mathrm{a}} \pm 0.35$ & $9.75^{\mathrm{a}} \pm 0.27$ & $9.38^{\mathrm{a}} \pm 0.35$ \\
\hline Color & $9.38^{\mathrm{a}} \pm 0.43$ & $9.18^{\mathrm{a}} \pm 0.29$ & $7.62^{\mathrm{a}} \pm 0.44$ & $9.38^{\mathrm{a}} \pm 0.44$ \\
\hline $\begin{array}{c}\text { Overall } \\
\text { acceptability }\end{array}$ & $9.50^{\mathrm{a}} \pm 0.46$ & $9.25^{\mathrm{a}} \pm 0.27$ & $9.19^{\mathrm{a}} \pm 0.29$ & $5.93^{\mathrm{c}} \pm 0.18$ \\
\hline
\end{tabular}

Data are expressed as mean $\pm S D$. Values within a row having different superscripts are significantly different ( $p \leq 0.05$ ); where the small letters indicate significant among dietary treatment groups as indicated by one-way ANOVA followed by Duncan's multiple range test $(a>b>c>d>e)$ 
Abeer A. Khedr, El-Beltagy, A and Marwa, M Shabana

\section{التأثيز الخافض للأهون الدم لمسحوق مخلفات الطماطم المجفةهة عنى إناث المرذذان المسنة \\ عبيز احمد خضر 1 ، علاء السبد البلتاجى ، مروة محمد شبانة ا ا.قسم التغذية و علوم الاطعمة كلية الاقتصاد المنزلى جامعة المنوفيةـ شبن الكوم ـ مصر قسم علوم وتكنولوجيا الاغذية ـ كلية الزر اعة جامعة المنوفية سشبين الكوم -مصر الملخص العربي}

مخلفات الطماطم غنية بالمركات الفعالة و تمتلك خصائص علاجية على الرغم من قبيتها الاقتصادية

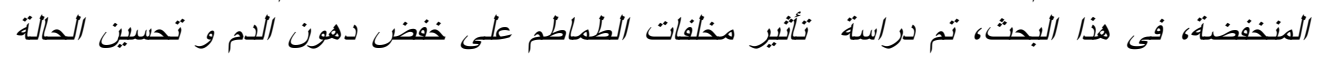

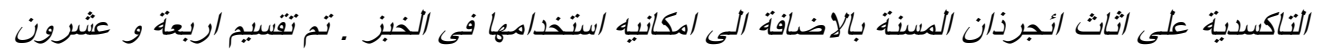

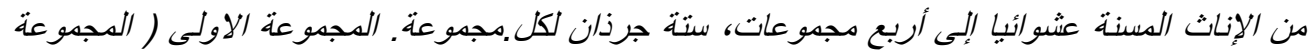

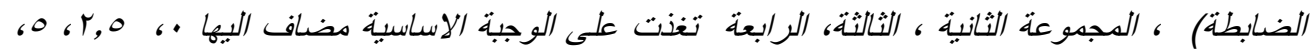

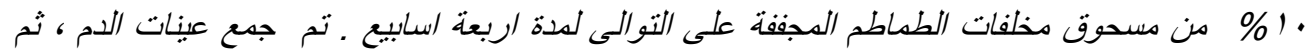

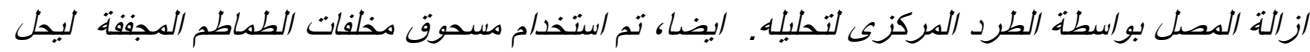

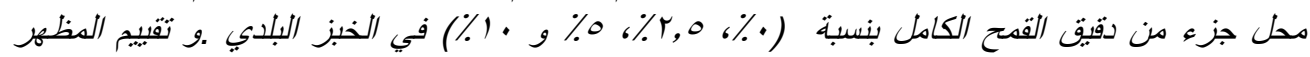

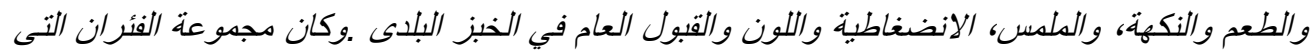

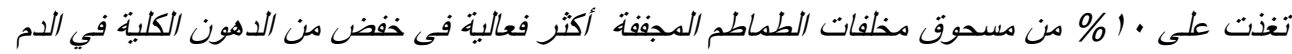

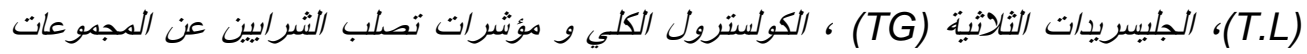

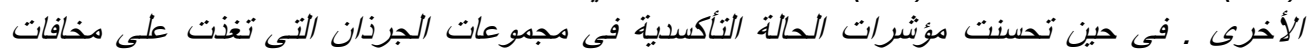

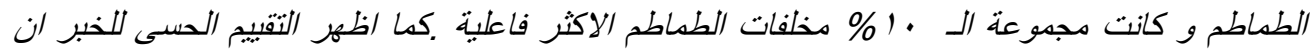

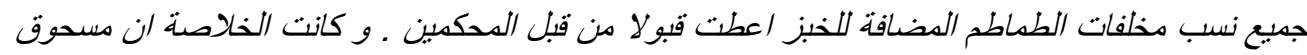

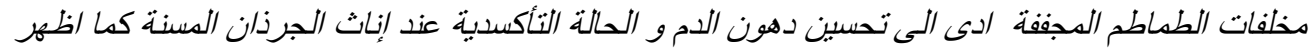

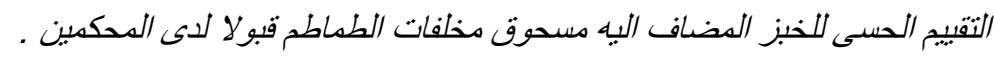
كلمات البحث: اناث الجرذان المسنة - مخلفات الطماطم المجفةة - دهون الدم - الخبز . 